\begin{tabular}{c|c|c|c|c|c|c|c|} 
DOI: http://dx.doi.org/10.54085/ap.covid19.2021.10.2.2 \\
Annals of Phytomedicine: An International Journal \\
http://www.ukaazpublications.com/publications/index.php \\
Print ISSN : 2278-9839
\end{tabular}

\title{
Effectiveness and outcome of Unani medicine interventions on population at risk of COVID-19
}

\author{
Asim Ali Khan*, Naheed Parveen, Rahat Raza*, Seema Akbar**, Haseeb Ahmed Lari***, Parvez Khan****, M. Fazi**, Ghazala \\ Javed, Pradeep Kumar, R.P. Meena, Jamal Akhtar, Nighat Anjum, Shaista Urooj*, Anirban Rej and Shoeb Mumtaz \\ Central Council for Research in Unani Medicine, 61-65, Institutional Area, Opp. D block Janakpuri, New Delhi. 110058, India \\ * Regional Research Institute of Unani Medicine, New Delhi-110025, India \\ ** Regional Research Institute of Unani Medicine, Srinagar-190006, India \\ *** Regional Research Institute of Unani Medicine, Mumbai-400008, India \\ **** Regional Research Institute of Unani Medicine, Aligarh-202201, India
}

\section{Article Info}

\section{Article history}

Received 26 October 2021

Revised 13 December 2021

Accepted 14 December 2021

Published Online 30 December 2021

\section{Keywords}

Khamira Marwareed

Tiryaq Arba

Unani Joshanda

Quality of life

COVID-19

\begin{abstract}
The novel coronavirus disease (COVID-19) is caused by severe acute respiratory syndrome coronavirus 2 (SARS-CoV-2). The immune response to SARS-CoV-2 can play an important role in disease pathogenesis and clinical manifestations. Considering the antiviral, immuno-modulatory, anxiolytic, antiinflammatory and antioxidant properties, this open labelled, controlled, interventional, prophylactic study was conducted on individuals at risk in containment zones of different cities of India, viz., Lucknow, Aligarh, New Delhi, Srinagar, Mumbai and Bengaluru. The study focuses on number of patients turning COVID-19 positive, change in ISQ and WHOQOL-BREF scales in both the groups. Apparently, healthy individuals at risk in containment zones were divided into intervention and control groups. The intervention group was further divided into two subgroups. The first subgroup received Unani regimenI including Unani Joshanda with Khamira Marwareed (KM), the second subgroup received Unani regimenII including Unani Joshanda with Tiryaq Arba (TA). The control group did not receive any intervention. The duration of intervention was 20 days; follow ups were planned on day 10 , day 20 and day 35 . A total number of 33021 participants were enrolled in the study, of which 30,931 participants completed the study. It was observed that individuals receiving Unani regimen-I demonstrated lower risk of developing COVID-19 by $74 \%$ and those receiving Unani regimen-II by $62 \%$ in comparison to the control group. Interventional groups showed highly significant $(p<0.001)$ effect on the quality of life.
\end{abstract}

\section{Introduction}

The novel coronavirus disease is caused by severe acute respiratory syndrome coronavirus 2. The immune response of an individual against to SARS-CoV-2 can play a vital role in disease pathogenesis and clinical manifestations (Petrova, 2018; Tan and Hardeland, 2020). Therefore, it is important to utilize any substance that can limit the viral effects. Developing antiviral drugs for COVID-19 is a challenge as viruses can vary in its effects on the immune system. SARS-CoV2 activates antiviral immune responses and may also cause uncontrolled inflammatory responses, which is characterized by marked pro-inflammatory cytokine release in severe COVID-19 patients, leading to lymphopenia, lymphocyte dysfunction, monocyte and granulocyte abnormalities (Qin et al., 2020). These SARS-CoV-2 induced immune abnormalities may lead to infections by microorganisms, septic shock, and severe multiple organ dysfunction (Meradand Martin, 2020). Therefore, underlying mechanisms for immune abnormalities in with COVID-19 patients

Corresponding author: Dr. Asim Ali Khan

Professor and Director General, Central Council for Research in Unani Medicine, 61-65, Institutional Area, Opp. D block Janakpuri, New Delhi. 110058, India

E-mail: unanimedicine@gmail.com

Tel.: +96-9811794448

Copyright () 2021 Ukaaz Publications. All rights reserved.

Email: ukaaz@yahoo.com; Website: www.ukaazpublications.com must be explained to guide clinical management of the disease. Moreover, rational management of the immune responses to SARSCoV-2 may be key to successful treatment, which includes enhancing antiviral immunity while inhibiting systemic inflammation (Petrova, 2018; Tanand Hardeland, 2020). Immunomodulators may be promising alternatives to classical treatment of the viral diseases for enhancing host defence responses. In such a scenario, immune modulators better equip the host in defending itself against invading micro-organisms; does not involve the use of organism-specific therapeutics and enhances better host originated mechanisms to participate in the immune response (Tzianabos, 2000).

The preventive measures for such epidemic diseases are mainly aimed towards the prevention of spread of infection by creatinga wareness about hygiene, antiseptic measures and promotion of general health. Major onus of these measures is to improve the host defence (Nikhat, 2020).

Unani medicine has placed great emphasis on the prevention of disease and promotion of health. The system has described six essential factors (Asbab-e-Sitta Zarooriyah) for the maintenance of health. Improving immunity is one of the key approaches for prevention of disease and promotion of health in Unani medicine. Therefore, Unani medicine has advocated a strategy to enhance immunity and to provide symptomatic relief in upper respiratory tract infection (Sina, YNM). 
Khamira Marwareed (KM), a classical standardized Unani polyherbal formulation is a general tonic and is used in neuro-asthenia (Zof-e-Asab), cardiac-aesthenia (Zof-e-Qalb), palpitation (Khafkhan), cerebro-asthenia (Zof-e-Dimagh) and polydiypsia (Atash-e-mufrit) (Anonymous, 2006; Khan et al., 2011). Another classical standardized Unani polyherbal formulation Tiryaq Arba (TA) is classically attributed with antidote (Tiryaq), deobsturent (Mufatteh), antispasmodic (Daf-e-tashannuj) and diuretic (Mudir) properties. It is used in the treatment of epilepsy (Sara), paralysis (Falij), and phlegmatic diseases (Balghami-amraz) (Arzani, 2009; Bagli, 2012; Ahsan and Rani, 2019).

The Unani Joshanda (decoction) consisting of Behidana (seed of Cydonia oblonga Mill.; Angiosperms: Rosaceae), Unnab (fruit of Zizyphus jujuba Mill.; Angiosperms: Rhamnaceae) and Sapistan (fruit of Cordia myxa Linn.); Angiosperms: Boraginaceae) has evidences of its antiviral, immune modulator, anti-oxidant and broncho-relaxant activity (Al-Bayatyand Al-Tahan, 2008; Hamauzu et al., 2005; Chi et al., 2015). Quality control studies of the Unani Joshanda conducted by the Central Council for Research in Unani Medicine have demonstrated that the preparation is free from any toxic substances. Similarly, insilico studies are indicative of its potential to inhibit the $\mathrm{S}$ protein and Mpro of SAR-CoV-2 besides, its ability to boost immunity.

Keeping in view, the efficacy of these Unani formulations, the current study was carried out in the identified containment zone/ quarantine facility with at least one confirmed COVID-19 positive case. The objective of the study was to compare number of individuals turning COVID-19 positive receiving Unani regimen-I and II with those receiving no intervention.

\section{Materials and Methods}

The present study was conducted in the identified containment zone/ quarantine facility in the respective cities through Central Research Institute of Unani Medicine (CRIUM), Lucknow (U.P.), Regional Research Institutes of Unani Medicine (RRIUM), Aligarh (U.P.), Srinagar (J and K), New Delhi and Mumbai (Maharashtra) and National Institute of Unani Medicine (NIUM), Bengaluru (Karnataka) during May to August 2020. The protocol was prepared by a multidisciplinary group of scientists of the CCRUM and vetted by the Interdisciplinary AYUSH Research and Development Task Force setup by Ministry of AYUSH, Government of India.

Subsequent to ethical approval from Central Ethics Committee (CEC) of the CCRUM (Central Council for Research in Unani Medicine) and CTRI registration (CTRI/2020/05/025254), individuals of either gender in the age group of 18-68 years were enrolled in the study after obtaining their written informed consent. Symptomatic or asymptomatic COVID-19 positive patients, pregnant or lactating women, persons exhibiting severe primary respiratory disease or related complications that can be associated with COVID-19, serious critical or mental illness, uncontrolled, unstable co-morbidities, immuno-compromised patients or those on immune-suppressants and steroids, individuals having a past history of allergy to any Unani interventional medicine were excluded. The study was open label, controlled, interventional, non-randomized, community-based clinical study. The sample size was 10,000 in each arm bringing the total sample size of the study to 30,000 complete cases (excluding dropouts).

Table 1: Ingredients of Unani regimen

\begin{tabular}{|c|c|c|c|}
\hline Unani name & Botanical Name & English name & Quantity \\
\hline \multicolumn{4}{|c|}{ Khamira Marwareed (KM) } \\
\hline Marwareed & Pearls from Mytilus margaritiferus & Pearl & $25 \mathrm{~g}$ \\
\hline Tabasheer & Root of Bambusa ardundinacea (Retz) Willd. & Common bamboo & $25 \mathrm{~g}$ \\
\hline Sandal & Wood of Santalum album Linn. & Sandal & $25 \mathrm{~g}$ \\
\hline Ambar & Ambra grasea & Ambar & $10 \mathrm{~g}$ \\
\hline Arq e Gulab & Rosa damascena Mill. distillate & Rose & $1 \mathrm{~L}$ \\
\hline Arq Baidmushk & Salix capera Linn. distillate & Pussy willow & $1 \mathrm{~L}$ \\
\hline Qand safed & & Sugar & $1.2 \mathrm{~kg}$ \\
\hline \multicolumn{4}{|l|}{ Tiryaq Arba (TA) } \\
\hline Juntiyana & Root of Gentiana lutea Linn. & Yellow gentian & 1 part \\
\hline Zarawand Taweel & Root of Aristolochia longa Linn. & Long aristolochia orsarrasine & 1 part \\
\hline Mur Makki & Resin of Commiphora myrrha (nees)Engl. & Myrrh & 1 part \\
\hline Habbul Ghar & Leaves of Laurus nobilis Linn. & Bay laurel & 1 part \\
\hline Asal/Qand safed & & Honey or sugar & Q.S. \\
\hline \multicolumn{4}{|l|}{ Unani Joshanda } \\
\hline Behidana & Seed of Cydonia oblonga Mill. & Quince fruit & $5 \mathrm{~g}$ \\
\hline Unnab & Fruit of Zizyphus jujube Mill. & Common jujube & 5 in number \\
\hline Sapistan & Fruit of Cordia myxa Linn. & Sebsten plum & 5 in number \\
\hline
\end{tabular}


The selected individuals were divided into two groups, i.e., intervention and control groups. The intervention group was further divided into two subgroups. Both the subgroups received $125 \mathrm{ml}$ of Unani herbal decoction consisting of Behidana (seed of Cydonia oblonga Mill.), Unnab (fruit of Zizyphus jujuba Mill.) and Sapistan (fruit of Cordia myxa L.) in the evening. Additionally, Unani regimen -I subgroup received $5 \mathrm{~g}$ of Khamira Marwareed (KM) in the morning whereas, Unani regimen-II subgroup received $5 \mathrm{~g}$ of Tiryaq Arba (TA) in the morning (Table 1). The control group received no medicine. All participants were asked to follow the general measures/guidelines issued by the Ministry of Health and Family Welfare/Ministry of AYUSH, Govt of India and World Health Organization (WHO)/State government and local health authorities. Any mandatory general measures recommended by Government Health Authorities were given in both arms of study. The drugs of the same batch were dispensed for the complete treatment period at first visit itself. Khamira Marwareed bearing batch no. MKM034-35 and Tiryaq Arba bearing batch no. IME0099 were provided by CCRUM. The duration of the protocol therapy was 20 days.
The data was collected through door-to-door survey at day 0 (baseline) and day 20 (at the end of the study) and telephonically on day 10 and day 35 for post-trial access. The data was recorded in a Case Record Form (CRF). The objective of the study was to compare number of individuals turning COVID-19 positive receiving Unani regimen-I and II with those receiving no intervention. Participants were assessed on the basis of turning COVID-19 positive receiving Unani regimen-I and II with those receiving no intervention.

They were also assessed on Immune Status Questionnaire (ISQ) and WHO QOL-BREF Questionnaire. Any adverse events occurring during the period were recorded in the CRF. Participants who developed COVID-19 symptoms with positive RT-PCR were notified to the concerned district authorities for shifting to a COVID-19 treatment facility.

The data was analysed based on per protocol analysis. Objective and subjective parameters were analysed to univariate and multivariate analysis using Statistical Package for Social Sciences (SPSS) Ver.25.0.

Table 2: Age-wise distribution of the patients in Intervention and Control group

\begin{tabular}{|l|l|l|l|}
\hline \multirow{2}{*}{ Age group (Years) } & \multicolumn{2}{|c|}{ Gender } & \multirow{2}{*}{ Total } \\
\cline { 2 - 3 } & Male (\%) & Female (\%) & \\
\hline $18-28$ & $5445(31.03 \%)$ & $4512(33.72 \%)$ & 9957 \\
\hline $29-39$ & $4365(24.87 \%)$ & $3682(27.52 \%)$ & 8047 \\
\hline $40-50$ & $4472(25.48 \%)$ & $3186(23.81 \%)$ & 7658 \\
\hline $51-60$ & $2287(13.03 \%)$ & $1480(11.06 \%)$ & 3767 \\
\hline$>60$ & $981(5.59 \%)$ & $521(3.89 \%)$ & 1502 \\
\hline Total & 17550 & 13381 & 30931 \\
\hline Mean \pm SD & $\mathbf{3 7 . 7 0} \pm \mathbf{1 3 . 4 4}$ & $\mathbf{3 6 . 2 8} \pm \mathbf{1 2 . 9 1}$ & $\mathbf{3 7 . 0 9} \pm \mathbf{1 3 . 2 3}$ \\
\hline Median & $\mathbf{3 6}$ & $\mathbf{3 5}$ & $\mathbf{3 5}$ \\
\hline
\end{tabular}

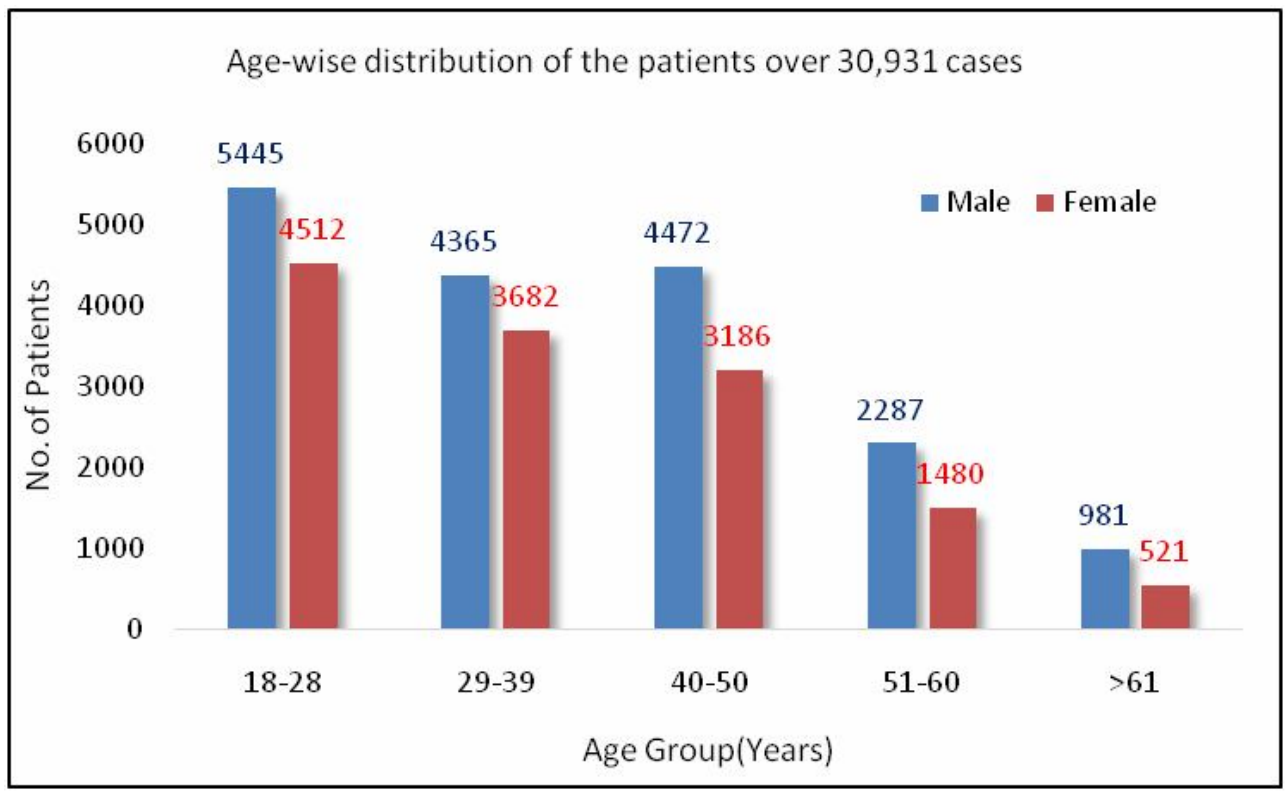

Figure 1: Age-wise distribution of the patients in Intervention and Control group. 
Table 3: Distribution of Temperament according to Age and Gender

\begin{tabular}{|c|c|c|c|c|c|c|c|c|c|c|}
\hline \multirow{3}{*}{$\begin{array}{c}\text { Age } \\
\text { ( in Years) }\end{array}$} & \multicolumn{8}{|c|}{ Temperament } & \multirow{2}{*}{\multicolumn{2}{|c|}{ Total }} \\
\hline & \multicolumn{2}{|r|}{ Damvi } & \multicolumn{2}{|c|}{ Saudavi } & \multicolumn{2}{|c|}{ Safravi } & \multicolumn{2}{|c|}{ Balghami } & & \\
\hline & Male & Female & Male & Female & Male & Female & Male & Female & Male & Female \\
\hline $18-28$ & 2661 & 1964 & 569 & 526 & 940 & 814 & 1275 & 1208 & 5445 & 4512 \\
\hline $29-39$ & 1782 & 1343 & 600 & 443 & 686 & 691 & 1197 & 1205 & 4365 & 3682 \\
\hline $40-50$ & 1437 & 820 & 694 & 478 & 837 & 588 & 1504 & 1300 & 4472 & 3186 \\
\hline $51-60$ & 581 & 306 & 456 & 282 & 408 & 238 & 842 & 654 & 2287 & 1480 \\
\hline$>60$ & 236 & 120 & 207 & 119 & 165 & 73 & 373 & 209 & 981 & 521 \\
\hline Total & 6697 & 4553 & 2526 & 1848 & 3036 & 2404 & 5191 & 4576 & 17550 & 13381 \\
\hline
\end{tabular}

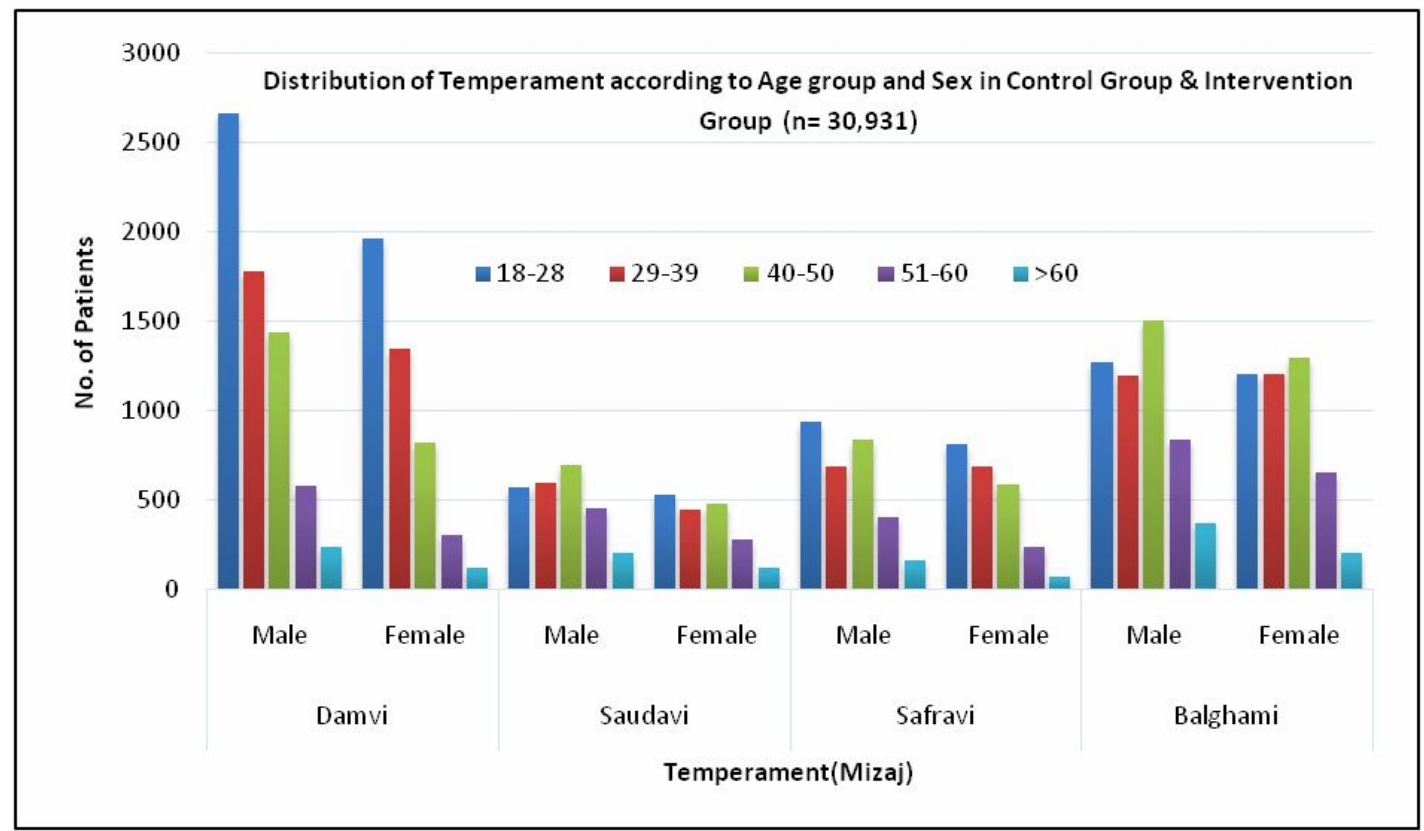

Figure 2: Distribution of Temperament according to Age and Gender in Intervention group.

\section{Results}

In the present study, a total no of 33021 participants were enrolled in the study from the identified containment zones. Out of these, 30931 (93.67\%) participants completed the study. A total of 1673 (5.07\%) dropped out because of non-compliance or lost to follow up whereas, $417(1.26 \%)$ developed symptoms associated with COVID-19 like fever, headache, muscle pain, cough.

\subsection{Demographic findings}

Maximum number of participants 7931 (25.64\%) were from Mumbai (Maharashtra), followed by 7588 (24.53\%) participants from New Delhi, 4699 (15.20\%) participants from Lucknow, 4617 (14.93\%) participants from Srinagar (Jammu and Kashmir), 3048 (9.85\%) participants from Aligarh (Uttar Pradesh) and 3048 (9.85\%) participants from Bengaluru (Karnataka). This depicts the pan Indian expression of the data from various ethnic groups.

The mean age of the participants was $37.09 \pm 13.23$. Of these, 9957 $(32.19 \%)$ participants were within the age group of $18-28$ years.
$56.74 \%$ of the participants were male with a mean age of $37.70 \pm$ 13.44, while the mean age for females was $36.28 \pm 12.91$ (Table 2, Figure 1).

A total number of 6697 (21.65\%) males with Damvi (sanguineous) temperament participated in the study. This was followed by 5191 (16.78\%) males with Balghami (phlegmatic) temperament (Table 3, Figure 2).

\subsection{Relative risk of developing COVID-19}

The study showed that $0.92 \%$ and $1.32 \%$ participants in Intervention group receiving Unani regimen-I and Unani regimen-II, respectively developed COVID-19 or COVID like symptoms in comparison to $3.49 \%$ participants in control group. Individuals receiving Unani regimen-I had $74 \%$ (relative risk ratio 0.26 ) where as those receiving Unani regimen-II had a $62 \%$ (relative risk ratio 0.38 ) lower risk of developing COVID-19 (Table 4 A, B). 
3.3 Immunity status as assessed with Immunity Status Questionnaire (ISQ)

The study showed that the mean change in total ISQ score of Unani regimen-I group over control group is 0.622 and that of Unani regimen-II group over control group is 0.79 (Table 5).
3.4 Quality of life as measured with WHO QOL BREF

The study showed that the mean change in quality of life of participants in Intervention group receiving Unani regimen-I and Unani regimen-II over control group is 0.32 and 0.95 in the physical domain, 0.56 and 1.11 in psychological domain, 0.05 and 0.3 in social domain and 0.31 and 0.29 in environmental domain, respectively (Table 6, Figure 3 ).

Table 4A: Relative Risk Ratio in the Unani regime-I and Control group

\begin{tabular}{|l|l|l|l|l|}
\hline Treatment group & $\begin{array}{l}\text { COVID-19 suspected } \\
\text { cases (positive) }\end{array}$ & Negative cases & Total & Cumulative incidence \\
\hline Intervention group & 95 & 10,207 & 10,302 & $95 / 10302=0.0092$ \\
\hline Control group & 358 & 9,882 & 10,240 & $358 / 10240=0.0349$ \\
\hline \multicolumn{2}{|c|}{ Risk ratio $=\frac{0.0092}{0.0349}=0.26$} \\
\hline Percentage Relative Effect $(1-\mathrm{RR}) * 100=74 \%$ \\
\hline
\end{tabular}

Table 4B: Relative Risk Ratio in the Unani regime-II and Control group

\begin{tabular}{|l|l|l|l|l|}
\hline Treatment group & $\begin{array}{l}\text { COVID-19 } \\
\text { suspected cases } \\
\text { (positive) }\end{array}$ & Negative cases & Total & Cumulative incidence \\
\hline Intervention group & 137 & 10,252 & 10,389 & $137 / 10389=0.0132$ \\
\hline Control group & 358 & 9,882 & 10,240 & $358 / 10240=0.0349$ \\
\hline \multicolumn{5}{|r|}{ Risk ratio $=\frac{0.0132}{0.0349}=0.38$} \\
\hline Percentage Relative Effect (1-RR)*100 $=62 \%$ \\
\hline
\end{tabular}

Table 5: ISQ Scores parameter wise distribution of subjects

\begin{tabular}{|c|c|c|c|c|c|c|c|c|c|c|c|c|}
\hline \multirow{4}{*}{$\begin{array}{l}\text { ISQ Scores } \\
\text { Sudden high fever }\end{array}$} & \multirow{2}{*}{\multicolumn{2}{|c|}{$\begin{array}{l}\text { Intervention group (TA) } \\
(\mathbf{n}=\mathbf{1 0 3 8 9})\end{array}$}} & \multirow{2}{*}{\multicolumn{2}{|c|}{$\begin{array}{l}\text { Intervention group (KM) } \\
(\mathbf{n}=\mathbf{1 0 3 0 2})\end{array}$}} & \multirow{2}{*}{\multicolumn{2}{|c|}{$\begin{array}{l}\text { Control group }(n=10240) \\
\text { Follow-up Period }\end{array}$}} & \multicolumn{2}{|c|}{$\begin{array}{l}\text { Intervention } \\
\text { group (TA) }\end{array}$} & \multicolumn{2}{|c|}{$\begin{array}{l}\text { Intervention } \\
\text { group (KM) }\end{array}$} & \multicolumn{2}{|c|}{ Control group } \\
\hline & & & & & & & \multicolumn{6}{|c|}{ Improvement (Mean changes) } \\
\hline & \multirow{2}{*}{$\begin{array}{l}\text { Base Line } \\
0.54 \pm 0.69\end{array}$} & \multirow{2}{*}{$\begin{array}{l}\text { End of the } \\
\text { study } \\
0.28 \pm 0.49\end{array}$} & \multirow{2}{*}{$\begin{array}{l}\text { Base Line } \\
0.62 \pm 0.61\end{array}$} & \multirow{2}{*}{$\begin{array}{l}\text { End of the } \\
\text { study } \\
0.37 \pm 0.54\end{array}$} & \multirow{2}{*}{$\begin{array}{l}\text { Base Line } \\
0.38 \pm 0.55\end{array}$} & \multirow{2}{*}{$\begin{array}{l}\begin{array}{l}\text { End of the } \\
\text { study }\end{array} \\
0.33 \pm 0.68\end{array}$} & \multicolumn{2}{|c|}{$\begin{array}{l}\text { Base Line vs End } \\
\text { of the study }\end{array}$} & \multicolumn{2}{|c|}{$\begin{array}{l}\text { Base Line vs } \\
\text { End of the } \\
\text { study }\end{array}$} & \multicolumn{2}{|c|}{$\begin{array}{l}\text { Base Line vs } \\
\text { End of the } \\
\text { study }\end{array}$} \\
\hline & & & & & & & -0.259 & $\downarrow$ & -0.256 & $\downarrow$ & -0.053 & $\downarrow$ \\
\hline Diarrhoea & $0.65 \pm 0.67$ & $0.48 \pm 0.63$ & $0.71 \pm 0.59$ & $0.54 \pm 0.58$ & $0.37 \pm 0.56$ & $0.27 \pm 0.52$ & -0.177 & $\downarrow$ & -0.173 & $\downarrow$ & -0.096 & $\downarrow$ \\
\hline Headache & $1.26 \pm 0.80$ & $1.10 \pm 0.90$ & $1.07 \pm 0.64$ & $0.91 \pm 0.64$ & $0.71 \pm 0.79$ & $0.56 \pm 0.79$ & -0.166 & $\downarrow$ & -0.162 & $\downarrow$ & -0.145 & $\downarrow$ \\
\hline $\begin{array}{l}\text { Skin problems (e. g. } \\
\text { acne\&eczema) }\end{array}$ & $0.81 \pm 0.94$ & $0.64 \pm 0.84$ & $0.64 \pm 0.81$ & $0.56 \pm 0.77$ & $0.46 \pm 0.74$ & $0.43 \pm 0.73$ & -0.164 & $\downarrow$ & -0.073 & $\downarrow$ & -0.038 & $\downarrow$ \\
\hline Muscle and joint pain & $1.86 \pm 1.22$ & $1.69 \pm 1.34$ & $1.08 \pm 0.95$ & $0.96 \pm 0.90$ & $0.78 \pm 0.87$ & $0.68 \pm 0.87$ & -0.170 & $\downarrow$ & -0.122 & $\downarrow$ & -0.096 & $\downarrow$ \\
\hline Common Cold & $1.17 \pm 0.74$ & $0.83 \pm 0.83$ & $1.06 \pm 0.55$ & $0.69 \pm 0.66$ & $0.81 \pm 0.75$ & $0.58 \pm 0.77$ & -0.348 & $\downarrow$ & -0.370 & $\downarrow$ & -0.229 & $\downarrow$ \\
\hline Coughing & $0.82 \pm 0.66$ & $0.53 \pm 0.61$ & $0.86 \pm 0.58$ & $0.59 \pm 0.64$ & $0.68 \pm 0.76$ & $0.49 \pm 0.77$ & -0.293 & $\downarrow$ & -0.268 & $\downarrow$ & -0.192 & $\downarrow$ \\
\hline $\begin{array}{l}\text { I score my general } \\
\text { health }\end{array}$ & $7.82 \pm 2.03$ & $8.61 \pm 1.64$ & $4.17 \pm 3.43$ & $4.26 \pm 3.68$ & $7.28 \pm 1.44$ & $7.58 \pm 1.32$ & 0.788 & $\uparrow$ & 0.095 & $\uparrow$ & 0.294 & $\uparrow$ \\
\hline $\begin{array}{l}\text { I Score my immune } \\
\text { functioning }\end{array}$ & $7.91 \pm 1.97$ & $8.70 \pm 1.53$ & $4.36 \pm 3.59$ & $4.38 \pm 3.77$ & $7.31 \pm 1.40$ & $7.62 \pm 1.27$ & 0.785 & $\uparrow$ & 0.020 & $\uparrow$ & 0.311 & $\uparrow$ \\
\hline $\begin{array}{l}\text { ISQ Scores Final } \\
\text { Score }\end{array}$ & $6.13 \pm 1.91$ & $7.34 \pm 2.17$ & $7.02 \pm 1.82$ & $8.06 \pm 1.65$ & $8.06 \pm 1.33$ & $8.48 \pm 1.44$ & 1.207 & $\uparrow$ & 1.039 & $\uparrow$ & 0.417 & $\uparrow$ \\
\hline
\end{tabular}


Table 6: WHO-QOL-BREF questionnaire wise distribution of subjects

\begin{tabular}{|c|c|c|c|c|c|c|c|c|c|}
\hline \multirow{3}{*}{$\begin{array}{l}\text { WHO-QOL-BREF } \\
\text { domains }\end{array}$} & \multicolumn{2}{|c|}{$\begin{array}{l}\text { Intervention group (TA) } \\
(\mathbf{n}=10389)\end{array}$} & \multicolumn{2}{|c|}{$\begin{array}{l}\text { Intervention group (KM) } \\
(\mathrm{n}=10302)\end{array}$} & \multicolumn{2}{|c|}{ Control group $(n=10240)$} & $\begin{array}{l}\text { Intervention } \\
\text { group (TA) }\end{array}$ & $\begin{array}{l}\text { Intervention } \\
\text { group (KM) }\end{array}$ & $\begin{array}{l}\text { Control } \\
\text { group }\end{array}$ \\
\hline & \multicolumn{6}{|c|}{ Mean \pm SD } & \multicolumn{3}{|c|}{ Improvement (Mean changes) } \\
\hline & Base line & $\begin{array}{l}\text { End of the } \\
\text { study }\end{array}$ & Base line & $\begin{array}{l}\text { End of the } \\
\text { study }\end{array}$ & Base line & $\begin{array}{l}\text { End of the } \\
\text { study }\end{array}$ & $\begin{array}{l}\text { Base line vs } \\
\text { End of the } \\
\text { study }\end{array}$ & $\begin{array}{l}\text { Base line vs } \\
\text { End of the } \\
\text { study }\end{array}$ & $\begin{array}{l}\text { Base Line } \\
\text { vs End of } \\
\text { the study }\end{array}$ \\
\hline Domain 1 (Physical) & $21.75 \pm 2.71$ & $23.14 \pm 3.30$ & $22.95 \pm 3.67$ & $23.72 \pm 3.60$ & $21.61 \pm 2.76$ & $22.05 \pm 2.82$ & 1.39 & 0.76 & 0.44 \\
\hline $\begin{array}{l}\text { Domain } 2 \\
\text { (Psychological) }\end{array}$ & $18.81 \pm 2.58$ & $20.10 \pm 2.67$ & $18.82 \pm 3.23$ & $19.56 \pm 2.96$ & $18.45 \pm 2.79$ & $18.63 \pm 2.45$ & 1.29 & 0.73 & 0.18 \\
\hline Domain 3 (Social) & $9.51 \pm 1.71$ & $10.06 \pm 1.68$ & $9.21 \pm 1.74$ & $9.51 \pm 1.59$ & $9.15 \pm 1.67$ & $9.40 \pm 1.68$ & 0.55 & 0.30 & 0.25 \\
\hline $\begin{array}{l}\text { Domain } 4 \\
\text { (Environmental) }\end{array}$ & $24.18 \pm 3.96$ & $24.62 \pm 3.10$ & $22.64 \pm 4.60$ & $23.10 \pm 4.10$ & $23.66 \pm 4.37$ & $23.81 \pm 3.96$ & 0.44 & 0.45 & 0.15 \\
\hline
\end{tabular}

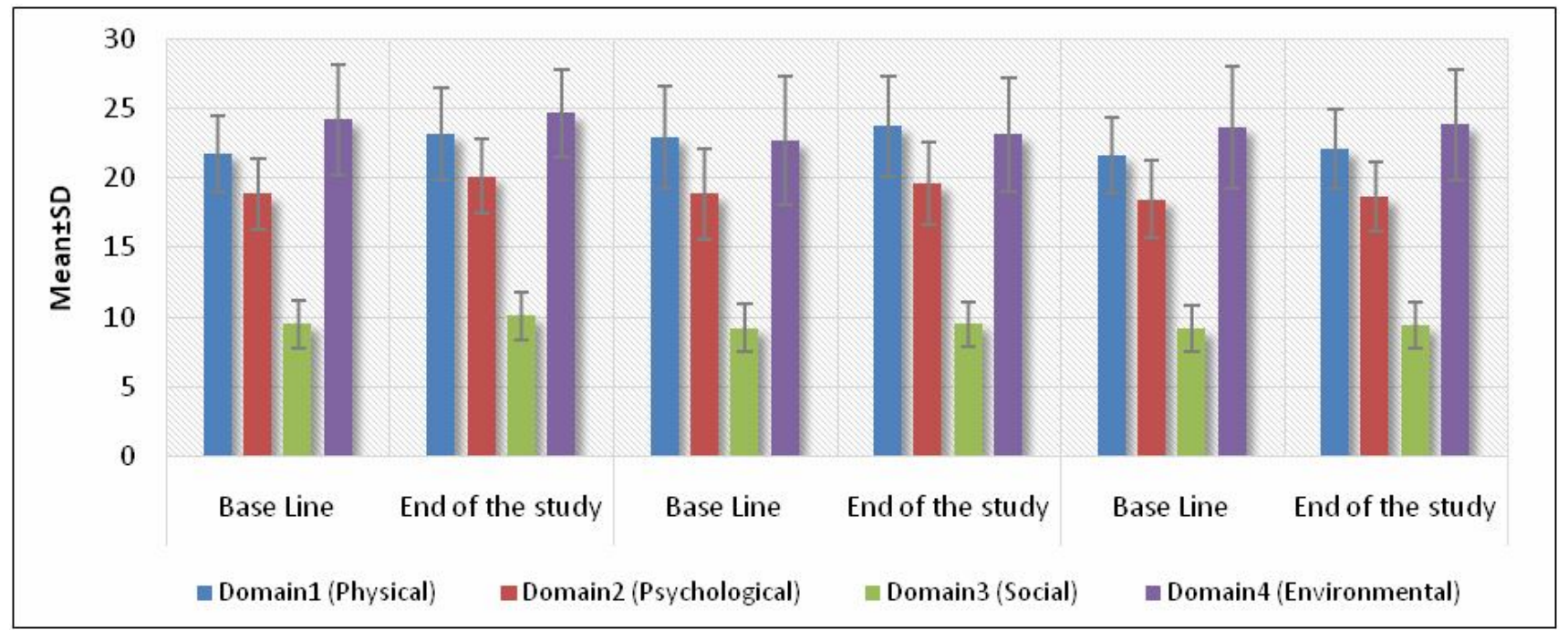

Figure 3: Distribution of patients according to WHO-QOL-BREF questionnaire.

\section{Discussion}

In the present study, a total no of 30931 participants completed the study. It was observed that male participation was higher with 4169 more males participating in the study bringing the male to female ratio to 1.3: 1 . The mean age difference between the male and female is $1.42 \pm 0.53$ years.

Mizaj (Temperament) is a unique characteristic of an individual developed due to interaction between different elements in the body affecting the normal physical and emotional state/reaction and defining morphological, physiological and psychological features of the individual (Mojahedi et al., 2014). Damvi (sanguineous) temperament participants out numbered other Mizaj (temperament) as Damvi (sanguineous) temperament individuals are attributed with optimistic attitude and probably that is why we have maximum number of participants from that temperament (Itrat, 2014).

It was observed that majority of the symptoms were present in all the groups between 10-20 days. This decreased susceptibility in the intervention group may be attributed to the immune-modulating effect of the Unani regimen-I and II. Interventional formulations, i.e., $\mathrm{KM}$ modulates the cell mediated immuno responses via cytokine modulation within 10-14 days (Khan et al., 2009) and TA increase CD3, CD4 and CD8 cells (Bagli, 2012). The immune modulatory effect of the ingredients of Unani Joshanda (decoction) may have attributed to the effect in the intervention group (Al-Bayaty and AlTahan, 2008; Hamauzu, 2005; Chi et al., 2015).

It is observed that there was an improvement in the immunity status of the participants in intervention and control groups. However, in the intervention group, the final ISQ scores in Unani regimen-II subgroup are marginally 0.168 (Mean changes) better than the Unani regimen-I subgroup. This could be because ingredients of KM and TA possess immunestimulatory and anti-oxidant activity (Mahboubi, 2016; Ansari, 2020).

The quality of life of the participants was assessed on WHO QOL BREF. The questions in physical domain were pertaining to activities of daily life, dependence on medical substances and aids, agility, mobility, pain, sleep, rest and work capacity. Under the psychological domain perception towards body image, feelings, self-esteem, believes, thinking, learning, memory and concentration were analysed.The social and environmental domains cannot be altered therapeutically, however, when the body is agile and the mind at peace, resilience increases.

The improvement in quality of life in the intervention group may be attributed to the immune-stimulatory, anti-inflammatory and antioxidant effect of the Unani regimen-I and II (Gadir, 2014; Mahboubi, 2016; Ansari, 2020 ). It was also observed that none of the participants have reported any adverse events during the study. 


\section{Conclusion}

It is concluded that out of the 33021 participants enrolled in the study from the identified containment zones, 30931 (93.67\%) participants completed the study. The study provides evidences of relative improvement in the quality of life in all domains including physical, psychological, social and environmental.

An improvement in the immunity status of the participants in intervention and control groups was observed. However, in the intervention group, the final ISQ scores in Unani regimen-II subgroup are marginally better than the Unani regimen-I subgroup. Khamira Marwareed (KM) an immune-modulator and general tonic offered $74 \%$ prophylactic protection against COVID-19; whereas TA an antidote provided $62 \%$ prophylactic protection against COVID-19.

It is concluded that Unani regimen-I and Unani regimen-II were found effective in decreasing the susceptibility of developing COVID19 or COVID like symptoms among the participants. The Unani regimens also improved the immunity status and quality of life. No adverse events were reported during the study.

\section{Acknowledgements}

We acknowledge Dr B.S.Prasad, President, Board of Ayurveda, NCISM, New Delhi, India for his valuable suggestions on the manuscript. We also place on record the efforts made by the officers and staff of RRIUM's Srinagar, New Delhi, Aligarh, Mumbai; CRIUM Lucknow; and NIUM, Bengaluru for data collection and compilation.

\section{Conflict of interest}

The authors declare no conflicts of interest relevant to this article.

Funding: The funding for the study was done by Ministry of AYUSH, Government of India.

\section{References}

Ahsan, M.T. and Rani, R. (2019). Pharmacognostical, physicochemical and microbiological standardisation of Tiryaq-E-Arba (An Unani Polyherbal Formulation). Int. J. Pharmacogn. Pharm. Sci., 1(1):1520.

Al-Bayaty, M. A. A. and Al-Tahan, F. J. (2008). Mechanism of the trachea smooth muscle relaxant activity of the Cordia myxa plant extract in sheep. Iraqi J. Vet. Sci., 32(2):214-226.

Anonymous, (2006). National Formulary of Unani Medicine (NFUM) Part I.; Central Council for Research in Unani Medicine, New Delhi, pp:111-112.

Ansari, S.; Ahmad, I.; Ali, M. and Maaz, M.(2020). "Tiryaq Arba" (a Polyherbal Unani Formulation) as prophylactic medicine against epidemics of acute respiratory viral infections. MEJRH, 7(3):e102965.

Arzani, A. (2009). Qarabadeen Qadri. Central Council for Research in Unani Medicine, New Delhi, pp:771.
Bagli, B. S.(2012). An adjuvant Trial on Tiryaq e Arba among HIV patients on first line ART; MD dissertation, NIUM, Bangalore.

Chi, A.; Kang, C.; Zhang, Y.; Tang, L.; Guo, H.; Li, H. and Zhang, K. (2015). Immunomodulating and antioxidant effects of polysaccharide conjugates from the fruits of Ziziphus jujuba on chronic fatigue syndrome rats. Carbohydr. Polym., 122:189-196.

Gadir, S. and Ahmed, I.(2014). Commiphora myrrha and Commiphora africana essential oils. J. Chem. Pharm. Res., 6(7):151-156.

Hamauzu, Y.; Yasui, H.; Inno, T.; Kume, C. and Omanyuda, M.(2005). Phenolic profile, antioxidant property, and anti-influenza viral activity of Chinese quince (Pseudocydo niasinensis Schneid.), quince (Cydonia oblonga Mill.), and apple (Malus domestica Mill.) fruits. J. Agric. Food Chem., 53(4):928-934.

Itrat, M. and Zulkifle, M. A.(2014). Temperamental approach in promotion of Health. Med. J. Islamic World Acad. Sci., 22(2):102-106.

Khan, F.; Ali, S.; Ganie, B. A. and Rubab, I. (2009). Immunopotentiating effect of Khamira Marwarid, anherbo-mineral preparation. Methods Find. Exp. Clin. Pharmacol., 31:513-22.

Khan, M. S.; Ahmad, W.; Singh, M.; Ansari, S. H.; Siddiqui, K. M. and Ahmad, S. (2011). Quality control analysis of Khamira Marwareed a Unani cardioprotective formulation. Planta Med., 77:92.

Mahboubi, M. (2016). Rosa damascena as holy ancient herb with novel applications. J. Tradit. Complement. Med., 6(1):10-16.

Merad, M. and Martin, J. C. (2020). Pathological inflammation in patients with COVID-19: A key role for monocytes and macrophages. Nat. Rev. Immunol., 20:355.

Mojahedi,M.; Naseri, M.; Majdzadeh, R.; Keshavarz, M.; Ebadini, M.; Nazem, E. and Isfeedvajani, M. S. (2014). Reliability and validity assessment of Mizaj questionnaire: A novel self-report scale in Iranian Traditional Medicine. Iran. Red Crescent Med. J., 16(3):e15924.

Nikhat, S. and Fazil, M. (2020). Overview of Covid-19; its prevention and management in the light of Unani medicine. Sci. Total Environ., 728: 138859

Petrova, V. N. and Russell, C. A. (2018). The evolution of seasonal influenza viruses. Nat. Rev. Microbiol., 16(1):60.

Qin, C.; Zhou, L.; Hu, Z.; Zhang, S.; Yang, S.; Tao, Y.; Xie, C.; Ma, K.; Shang, K.; Wang, W. and Tian, D. S. (2020). Dysregulation of immune response in patients with coronavirus 2019 (COVID-19) in Wuhan, China. Clin. Infect. Dis., 71(15):762-768.

Sina, I. (YNM). Al Qanoon fit Tib(Urdu Translation by Kantoori GH). Idara Kitabishifa, New Delhi, Vol.1-5:1464.

Tan, D. X. and Hardeland, R. (2020). Potential utility of melatonin in deadly infectious diseases related to the overreaction of innate immune response and destructive inflammation. Melatonin Res., 3(1):120 43.

Tzianabos, A. O. (2000). Polysaccharide immunomodulators as therapeutic agents: structural aspects and biological function. Clin. Microbiol. Rev., 13:523-533.

Asim Ali Khan, Naheed Parveen, Rahat Raza, Seema Akbar, Haseeb Ahmed Lari, Parvez Khan, M. Fazil, Ghazala Javed, Pradeep Kumar, R.P. Meena, Jamal Akhtar, Nighat Anjum, Shaista Urooj, Anirban Rej, Shoeb Mumtaz (2021). Effectiveness and outcome of Unani Medicine interventions on population at risk of COVID-19. Ann. Phytomed., Volume10, Special Issue2 (COVID-19): S5-S11. http://dx.doi.org/10.54085/ap.covid19.2021.10.2.2 